\title{
MACROECONOMIC STABILITY IN POLAND AGAINST THE BACKDROP OF UNION TENDENCIES IN LIGHT OF THE CONCEPT OF MSP
}

\begin{abstract}
This article aims to analyse the trends in the development of factors that determine the level of macroeconomic stability and to assess this level in Poland against the backdrop of different groups of European Union Member States (EU28 countries, Western Europe, Central and Eastern Europe, and Southern Europe) over the period 2006-2015 by using the Macroeconomic Stability Pentagon (MSP) method. The subjects of analysis in the presented method are the rate of economic growth (GDP), the unemployment rate (U), the rate of inflation (CPI), the public finance balance $(G)$, and the country's current account balance (CA). These values form the apexes of a pentagon scaled in such a way that the more desirable the indicator value, the further its corresponding apex is situated from the centre of the system. The article proposes establishing a joint area of the MSP based on a modified classic scale and a scale with regression (these approaches do / do not take into account, respectively, the negative influence of deflation on the general level of macroeconomic stability). The conducted analyses show that in recent years the EU28 countries have returned to the level of macroeconomic equilibrium prior to the crisis of 2008-2009. In Poland the MSP indicator has been growing since 2013 and has significantly exceeded the levels observed in Southern European countries. However, until 2015 its level was still lower than the average for the EU28 and the average set for the Central and East European countries. This was mainly due to the high level of unemployment, which despite a downward trend still remained above the EU average.
\end{abstract}

Aleksandra Jurkowska, Cracow University of Economics, Faculty of Finance and Law, Department of Banking, Rakowicka 27, 31-510 Kraków, Poland, e-mail: jurkowsa@uek.krakow.pl

Michał Boda, Cracow University of Economics, Faculty of Finance and Law, Department of Banking, Rakowicka 27, 31-510 Kraków, Poland, e-mail: bodam@uek.krakow.pl 
Keywords: economic policy, macroeconomic indicators, macroeconomic stability, Macroeconomic Stability Pentagon (MSP), MSP indicator.

JEL Classification: E52, E62, E63, G01.

\section{Introduction}

This article aims to analyse the trends in the development of factors that determine the level of macroeconomic stability and to assess this level in Poland against the backdrop of different groups of European Union Member States (EU28 countries, Western Europe, Central and Eastern Europe, and Southern Europe) over the period 2006-2015 by using the Macroeconomic Stability Pentagon (MSP) method. This method facilitates the construction of synthetic stability indicators for specific countries and regions and the comparison of these factors in space and time, which is why it is used to assess the competitiveness of specific economies and to formulate current and long-term economic policy goals. The basis of the concept was developed by A. W. Phillips and R. Mundell. In Poland, the expanded five-indicator model for assessing macroeconomic stability was proposed in 1990 by the Foreign Trade Research Institute (Walawski 2015, p. 69) and was later used by, among others, G. Kołodko (1993), to assess the level of optimisation of the competitive goals of economic policy.

\section{Method Presentation}

In MSP analysis, macroeconomic stability is identified as a state of general equilibrium in the economy, that is, an internal and external equilibrium, when the functions of production, demand, and supply for all factors of production form an internally dependent system (Walrasian equilibrium or Pareto efficiency). The subjects of the analysis in the method being presented are the rate of economic growth, the unemployment rate, the rate of inflation, the public finance balance, and the current account balance, whose values form the apexes of a pentagon scaled in such a way that the more desirable the indicator value, the further its corresponding apex is situated from the centre of the system. An optimal system is illustrated in Figure 1, while the total area of the pentagon is expressed by the following formula:

$$
M S P=[(\Delta G D P \cdot U)+(U \cdot C P I)+(C P I \cdot G)+(G \cdot C A)+(C A \cdot \Delta G D P)] \cdot K,
$$


where:

$\triangle G D P$ - rate of GDP growth (\%),

$U$ - unemployment rate (\%),

$C P I$ - consumer price index $(\%)$,

$G$ - ratio of budget balance to GDP,

$C A$ - ratio of current account to GDP (\%),

$K-1 / 2 \sin 72^{\circ}$ (a constant value of 0.4756 equal to half the sinus of the angle found at the central apexes of each of the triangles marked in Figure 1 by the letters a, b, c, d, e; this angle, by assumption, forms a fifth of a full angle thus measuring $72^{\circ}$ ).

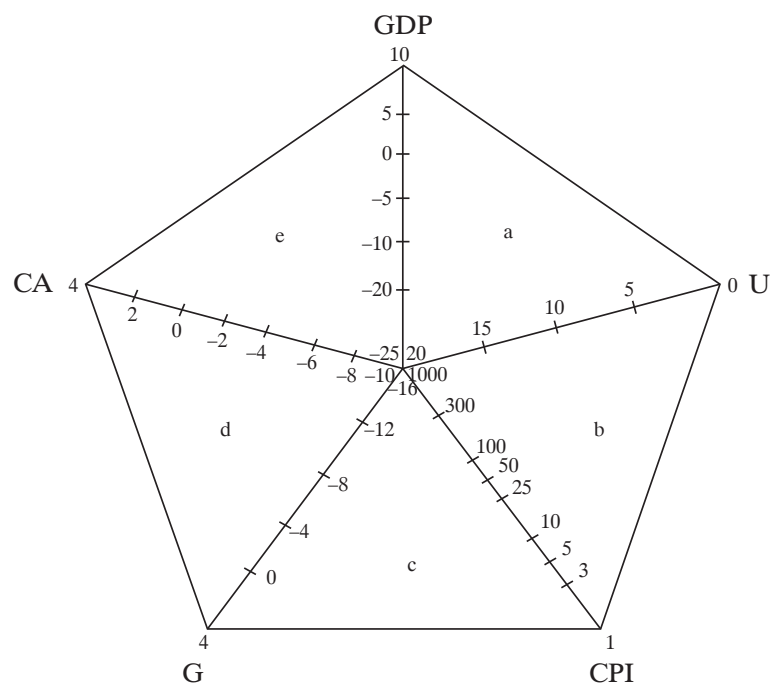

Fig. 1. The Optimal Shape of a Macroeconomic Stability Pentagon Source: (Siek 2015, p. 3).

The total area of the pentagon is the sum of the areas of the triangles labelled in Figure 1 by the letter a (a real sphere triangle whose area is dependent on the economic growth indicator and the unemployment rate), b (a stagflation triangle whose area depends on the unemployment rate and inflation), $\mathrm{c}$ (a budget and inflation triangle), $\mathrm{d}$ (a financial equilibrium triangle whose are is determined by the size of the budget balance and the current account balance) and e (an external sector triangle which is a function of the current account balance and GDP growth). The optimal state in an economy is when the area of the pentagon is equal to 1, that is, 
every triangle reaches its maximum size equal to $0.2(5 \times 0.2=1)$. This state is impossible to achieve due to many factors. The constituent parts of the MSP are area MSP1, which is dependent on internal factors (the sum of the areas of triangles $a, b$, and c), and area MSP2, which is dependent on external factors (the sum of the areas of triangles $d$ and e). The values of MSP1 and MSP2 make it possible to identify factors that determine the progress of the stabilisation or destabilisation process. When establishing the area of each triangle it is important to consider that their sides are scaled differently. Most of the scale units on the sides of the pentagon are expressed in percentage points. The exception is the side depicting the level of inflation, where a logarithmic scale is used (because of the large variation in the observed values). Because the classic model does not include the phenomenon of deflation, in this article the CPI axis has been appropriately scaled and the modified scale has been prepared as two variations: a) the outer limit has been set at $-2.0 \%$ - this method is recommended by K. Raczkowski (2016); the flaw of this approach is that only small scale deflation phenomena (when the rate of inflation drops from $+1.0 \%$ to $-2.0 \%$ ) are perceived as a desirable situation that positively influences the general level of macroeconomic stability; b) the outer limit, in accordance with the classic scale was set at $+1.0 \%$; with this approach every drop in inflation below the outer limit causes an appropriate shortening of the CPI side (scale with regression). Setting new outer limits was also necessary in the case of GDP, G, and CA (the limits were set at $15 \%, 10 \%$, and $15 \%$, respectively), because many of the indicators characteristic of the countries under review exceeded the classic scale. Despite these corrections, the exceptionally high economic growth rate in Ireland in 2015 (26.3\%) still fell outside the scale, which according to many economic event commentators did not fully reflect reality. As a result, in this paper, for the year 2015 Ireland has been assigned the maximum economic growth rate available on the modified classic scale $(15 \%)$.

\section{Macroeconomic Indicators in the European Union and Their Determinants}

According to the figures at the end of 2015, the EU economy was the biggest in the world with a GDP equal to 14.7 b EUR (http://ec.europa. eu/eurostat, accessed: 8 March 2017). In the joint GDP of the EU28, the biggest share belonged to Germany, France, the United Kingdom, Italy, and Spain. Despite having by far the greatest economic potential in the 
world from a nominal point of view, GDP per capita in EU countries was significantly lower than in the USA, and from 2008 the gap continued to grow. The average macroeconomic indicator values for EU countries in the years 2006-2015 are illustrated in Table 1.

Table 1. Average Macroeconomic Indicators in the EU*, 2006-2015 (\%)

\begin{tabular}{l|c|c|c|c|c|c|c|c|c|c}
\hline \multicolumn{1}{c|}{ Indicator } & 2006 & 2007 & 2008 & 2009 & 2010 & 2011 & 2012 & 2013 & 2014 & 2015 \\
\hline GDP $^{\mathrm{a}}$ growth rate & 5.1 & 5.0 & 1.2 & -5.6 & 1.7 & 1.7 & -0.4 & 0.5 & 2.3 & 3.3 \\
\hline Unemployment & 4.8 & 4.2 & 4.1 & 5.7 & 6.5 & 6.5 & 7.0 & 7.2 & 6.8 & 6.2 \\
\hline Inflation & 3.0 & 3.3 & 5.3 & 1.4 & 2.0 & 3.2 & 2.9 & 1.3 & 0.4 & -0.1 \\
\hline $\begin{array}{l}\text { Public finance } \\
\text { balance/GDP }\end{array}$ & -1.1 & -0.3 & -2.1 & -6.4 & -6.3 & -4.6 & -3.8 & -3.5 & -2.9 & -2.0 \\
\hline $\begin{array}{l}\text { Current account } \\
\text { balance/GDP }\end{array}$ & -4.1 & -5.0 & -4.9 & -1.3 & -1.1 & -0.8 & 0.1 & 1.4 & 1.7 & 2.2 \\
\hline
\end{tabular}

* average for the EU28, ${ }^{\text {a }}$ real GDP.

Source: authors' calculations based on: http://ec.europa.eu/eurostat (accessed: 8 March 2017).

From the end of Second World War until the end of the 1970s, Europe underwent a period of dynamic growth. In 2007, the rate of economic growth started to slow down and this trend continued until 2009, when EU countries experienced a recession (average GDP dropped by 5.6\%). The biggest drops in GDP were noted in the Baltic States (Lithuania, Latvia, and Estonia, where in 2009 GDP dropped by over 10\%), Finland, Slovenia, and Croatia (single-digit decrease). The key factor responsible for the economic slowdown was a gross decline in investments, caused mainly by a reduction in fixed asset expenditure (predominantly in the construction sector). The reduction was a reaction to earlier "overinvestment". The foreign trade balance had a positive influence and total consumption had a neutral influence (the drop in private consumption was offset by an increase in government spending) on the growth of GDP in Member States (Balcerowicz et al. 2016, pp. 9, 26-28). Following the introduction of government rescue schemes, in 2010 the average GDP growth of EU countries was $1.7 \%$, and the growth trend was maintained in 2011. In 2012, the average GDP of the EU28 countries in real terms was $0.4 \%$ lower than in the previous year. In the years 2013-2015, because of an increase in internal demand (mainly private) and investment stimulus financed by structural funds and company loans (World Bank 2015, p. 27 and 48), the European economies got back on the path of growth, though initially the fiscal changes and foreign trade balance had little effect 
on growth (EC 2014, p. 1-3). The pace of growth, however, varied across the EU. Analyses that take into account the cumulative growth of GDP per capita between 2008-2013 show that the countries developing the fastest were Poland, Slovakia, Lithuania, Bulgaria, Sweden, Germany, Malta, Estonia, and Latvia. Countries whose economies developed the slowest, beside the PIIGS countries, were Luxembourg, Slovenia, and Cyprus. In the majority of the second group countries, the economic slowdown was due to a decrease in net export (AMECO 2016, p. 29-31). In Southern Europe, the slump was connected to the drop in the competitiveness of economies, partly caused by the public finance crisis accompanied by a lack of wage discipline (Greece, Portugal) as well as delays in implementing the structural reforms laid out in the Lisbon Strategy and the "Europe 2020" strategy (Italy, Spain) (Albiński 2014, p. 24).

The economic slowdown in EU countries after 2007 was accompanied by an increase in the rate of unemployment between 2009 and 2013. In the first phase of the crisis (2008-2009), average unemployment rose by $1.6 \%$. Between 2009 and 2013, after the stabilisation programmes introduced by the governments of some countries were stopped, unemployment rose by another $1.5 \%$. In 2009, the largest growth in unemployment was recorded in countries that were the worst hit by the economic recession (the Baltic States) as well as Slovakia and Spain. Between 2009 and 2013, the total increase in unemployment was the highest in Greece, Cyprus, Spain, Croatia, Portugal, and Bulgaria. The highest annual rates of unemployment exceeded $20 \%$ and were recorded in Greece and Spain (http://ec.europa.eu/eurostat, accessed: 8 March 2017) between 2011 and 2014. In Spain, where the recession was at a moderate level, the labour market situation turned out to be very sensitive to changes in the economy and brought to light the ineffectiveness of the solutions introduced by the Nazara government, which were based on short-term contracts and "junk employment agreements" (Hajder 2013, p. 53). In the years 2014-2015, the clear acceleration in economic growth had a positive effect on the employment figures, and in 2015 the average rate of unemployment in EU countries dropped to $6.2 \%$.

Between 2006 and 2011, the average rate of inflation in EU Member States measured using the HICP indicator fluctuated between 1.4 and 5.3\%. A clear downward trend began in 2012; in 2015, average inflation stood at $-0.1 \%$, which prompted fears of deflation. Among the reasons for the deflationary pressure were: a drop in energy prices and a drop in internal demand (due to the slowing economy and more restrictive fiscal policy in the aftermath of the public finance crisis in the Eurozone) (Mastromatteo 
\& Rossi 2015, p. 336-50), and the associated "internal devaluation" in the PIIGS countries (Baldini \& Manasse (2016) as well as the raising of interest rates by the EBS in 2001 (Ducrozet, Kukla \& Lacan 2011, European Parliament 2015, Bednarczyk 2015), although opinions on this subject are divided. In European Union countries the divergence in inflation rates was far smaller than the divergence in economic growth or unemployment rates. At the end of 2015, the lowest (negative) inflation rates were recorded in 11 EU countries: Bulgaria, Greece, Spain, Croatia, Cyprus, Lithuania, Poland, Romania, Slovenia, and Finland. Only Malta had an inflation rate higher than $1 \%$.

In the years 2006/2007, the average EU budget deficit relative to GDP fell by 0.8 p.p., while in 2007 only two Member States exceeded the allowed $3 \%$ limit (one of the convergence conditions) - Greece and Hungary. Over the next two years the average negative balance of the EU government and local government sector grew to $-6.4 \%$, and in 2009 budgetary discipline limits were exceeded by 22 Member States (including Germany and Austria, who are seen as the most conservative in fiscal matters). In the period under analysis the highest deficit was recorded in 2010 in Ireland, where it stood at 32.1\% of GDP (http://ec.europa.eu/eurostat, accessed: 11 March 2017). The only, or certainly the primary, cause of growing deficits in EU countries was the increase in nominal budget spending, stemming more from current budgetary policy than from economic recession. In the PIIGS countries, the increase in budget spending was stimulated by an increase in pay that exceeded the increase in labour productivity, and by the bank crises (Albiński 2014). The improvement in the balance sheet of the government and local government sector registered from 2010 was primarily caused by an increase in revenue relative to budget spending, brought on by, among others, the effects of actions taken as part of fiscal consolidation (Giżyński 2012, pp. 179-193). In 2015, the average level of deficit in the EU28 settled at $2.0 \%$. Three Member States recorded a budget surplus (Germany, Estonia and Luxembourg). In six countries the deficit exceeded 3\% of GDP (http:// ec.europa.eu/eurostat, accessed: 11 March 2017) (Greece, Spain, France, Croatia, Portugal, and the United Kingdom), while nine were under the excessive budget deficit procedure (Croatia, Cyprus, France, Greece, Spain, Ireland, Portugal, Slovenia, and the United Kingdom).

During the period under analysis, the highest average current account deficit in the balance of EU payments was recorded in $2007(-5.0 \%$ of GDP). After 2009 this deficit gradually shrank, and in 2012 the average balance of current accounts closed with a surplus (0.1\% of GDP). 
The surplus persisted until 2015, showing a tendency towards growth. Before the recession, the current account balances of Member States were largely asymmetrical. The imbalance mainly concerned the so-called Eurozone core (Germany and North European countries recorded a high surplus) as well as Central and East European countries (Latvia, Estonia, Lithuania, Romania, Slovakia) and the PIIGS countries (where large deficits were recorded). In the literature on the subject, these imbalances are explained in two ways (Kuziemska 2010, p. 89-105; Belke \& Dreger 2011, p. 2). According to convergence theory, the deficits of poorer countries (as well as the surpluses of richer countries) form as a result of the free flow of capital, a reduction in national savings, and an influx of foreign investment. In the light of the theory of competitiveness, a real appreciation in the rate lowers the competitiveness of economies. After 2008, the average current account of the EU28 was a result of two trends (Kuziemska 2010, p. 102). First, countries with a large deficit at the beginning of the crisis experienced a drop in private sector demand (in PIIGS countries it was the result of implementing restrictive economic policy measures) and a slightly less drastic drop in exports. There were also changes to the internal demand structure: in particular, imported products were substituted by local ones. This resulted in a decrease in the deficit of current accounts. Second, in countries characterised by a current account surplus, private demand proved more resilient to perturbations, but a decrease in the current account balance was influenced by a growing public deficit and a drop in world trade (due to greater openness among economies). The result was a decrease (but not the elimination) of the current account surplus.

\section{Macroeconomic Indicators in Poland and Their Determinants}

Poland is the largest new Member State of the European Union. According to figures published at the end of 2015, it was in sixth place in the enlarged Union (EU-28) in terms of area, population, and GDP (7.1\%, 7.5\% and $2.9 \%$, respectively) and 24th in terms of GDP per capita (according to PPS $)^{1}$. Poland's share in the economic potential of the EU28 was therefore lower than it would seem from its geographical and demographic attributes (a similar disproportion concerns all the Central and East European countries), although Poland's position has improved significantly since

${ }^{1}$ Eurostat data and authors' own calculations based on Eurostat data (http://ec.europa.eu/eurostat, accessed: 11 March 2017). 
entering the European Union. The main macroeconomic indicators for Poland are illustrated in Table 2.

Table 2. Basic Macroeconomic Indicators for Poland, 2006-2015 (\%)

\begin{tabular}{l|c|c|c|c|c|c|c|c|c|c}
\hline \multicolumn{1}{c|}{ Indicator } & 2006 & 2007 & 2008 & 2009 & 2010 & 2011 & 2012 & 2013 & 2014 & 2015 \\
\hline GDP $^{\mathrm{a}}$ growth rate & 6.2 & 7.0 & 4.2 & 2.8 & 3.6 & 5.0 & 1.6 & 1.4 & 3.3 & 3.9 \\
\hline Unemployment & 13.9 & 9.6 & 7.1 & 8.1 & 9.7 & 9.7 & 10.1 & 10.3 & 9.0 & 7.5 \\
\hline Inflation & 1.3 & 2.6 & 4.2 & 4.0 & 2.6 & 3.9 & 3.7 & 0.8 & 0.1 & -0.7 \\
\hline $\begin{array}{l}\text { Public finance } \\
\text { balance/GDP }\end{array}$ & -3.6 & -1.9 & -3.6 & -7.3 & -7.3 & -4.8 & -3.7 & -4.1 & -3.4 & -2.6 \\
\hline $\begin{array}{l}\text { Current account } \\
\text { balance/GDP }\end{array}$ & -4.0 & -6.3 & -6.7 & -4.0 & -5.4 & -5.2 & -3.7 & -1.3 & -2.1 & -0.6 \\
\hline
\end{tabular}

${ }^{\mathrm{a}}$ real GDP.

Source: Eurostat data, http://ec.europa.eu/eurostat (accessed: 11 March 2017).

Between 2006 and 2008, the Polish economy was developing relatively fast - GDP growth stood at $4.2-7.0 \%$. As a result of the worldwide economic and financial crisis, the rate of growth dropped to $2.8 \%$ in 2009. However, Poland was the only EU country not to experience a recession. According to experts, the Polish development model relied on the private sector and resulted mainly from productivity gains, dynamic export growth, strong internal demand, the influx of EU funding, foreign direct investment, positive demographics, and a stable banking system (Bogdan et al. 2015, p. 12). It has also been emphasised that during the economic crisis the main growth stimulator was foreign demand - due to the strong depreciation of the zloty the Polish economy became more competitive on foreign markets, which is why in 2013 the current account balance was close to a state of equilibrium.

Unemployment in Poland until 2015 was regularly at a higher level than the EU-28 average. However, in the last few years of the period under analysis these differences diminished. Polish unemployment is characterised by strong regional variation. Other significant factors are variations due to gender and age. Unemployment is Poland depends not so much on the economic situation as on structure; it results from the level and structure of manpower resources failing to adjust to the real needs of the economy, which condemns some to professional idleness or the need to requalify, while unprofitable branches of production need to be restructured or liquidated (Głąbicka 2001, p. 91). According to research carried out thus far, it appears 
that unemployment in Poland is shaped mainly by variations in demand and, to a lesser extent, by factors such as the inflexibility of the labour market and the demotivating role of welfare benefits (Polakowski \& Szelewa 2013, p. 7; Bartosik 2012, p. 25-57). Consistently, the greatest challenges in the labour market are the high level of unemployment among young people and the labour participation rate (EC 2015, pp. 3-4).

The Maastricht criterion on price stability was already fulfilled by Poland in 2005-2007. In 2006, Poland (with an inflation rate of 1.3\%) found herself in the group of countries with the most stable prices. In 2009, the rate of inflation fell by 0.2 percentage points compared with 2008. In the years 2008-2009 and 2011-2012, the inflation rate in Poland was close to the optimal level, that is, it allowed for sustainable development (as estimated by P. Baranowski (2008, p. 109), the optimal level is 3.5-5\% for EU-15). The rapid drop of the HICP indicator between 2013 and 2015 (in 2015, for the first time since 1971, Poland recorded a negative inflation rate of $-0.7 \%$ ) should rather be associated with external factors: a moderate economic situation and a negative demand gap experienced by Poland's main trading partners (a drop in import prices partially limited by the consistently weak zloty) and a decrease in the price of food and fuels (MPC 2015, p. 17).

In the years 2006-2007, because of disciplined budget spending and better than expected economic indicators, it was possible to significantly reduce the budget deficit as a ratio of GDP (Konstanciak 2011, p. 58) - improvements in this area have been recorded since 2003). However, between 2008 and 2010 the deficit grew steadily (reaching a level of $-7.3 \%$ in 2009-2010), which was the general trend across Europe. In July 2009, the Council of the European Union placed Poland under the excessive deficit procedure, which obliged Poland to reduce the negative balance of public sector finances to $3 \%$ of GDP by 2012. In 2010, Poland became one of the European countries with the highest deficit in relative terms (besides the United Kingdom and the PIIGS countries). A major reason for the deterioration of the balance between 2008-2010 was the decline in budget revenue in relation to GDP, which was associated with budgetary policy at the time (the lowering of certain taxes and benefit contributions), the pro-cyclicality of tax revenue in Poland (especially company taxes), and changes in the tax system which allowed companies to reduce their tax base by losses incurred in previous years (Ministry of Finance 2012, pp. 13-15). In 2010, Poland belonged to the group of countries with the highest real and nominal GDP growth in the EU (along with Slovakia, Luxembourg, Germany, Malta, and Sweden), hence the changes in GDP were conducive 
to an improvement in the economic performance of the national budget. However, this opportunity could not be capitalised upon, mainly due to the inflexible nature of budget spending (most of which is made up of donations and subsidies) (Lubieniecka 2013, p. 250). According to D. Malinowski (2012, pp. 80-85), the main reason for the increase in the negative balance of public finances in 2010 was the growth in nominal budgetary spending, although what transpires from the Ministry of Finance report (2012, p. 27) is that the growth was mainly due to an increase in spending to finance EU projects. Meanwhile, its impact on the budget deficit was de facto neutral, because it was offset by equal amounts of revenue. According to S. Owsiak, the reason for increased spending and therefore the rise in the deficit during the economic crisis, was the need to co-finance EU projects with national public funding ${ }^{2}$, which is confirmed in the Ministry of Finance report. The drop in the ratio of the government and local government sector deficit to GDP from 2011 can be attributed to the relative increase in revenue and a drop in budgetary spending. Revenue began to grow as a result of, among others, an increase in the VAT rate (from January 2011), conditions favourable to GDP growth (a big increase in private consumption and public investment, a rise in the proportion of pension contributions to the Social Insurance Fund (FUS) (from May 2011), increases in excise duty, the procyclicality of company income tax, and from 2012 an increase in social security contributions (Ministry of Finance 2012, p. 23 and 29). The drop in spending was mainly the result of fiscal consolidation and the introduction of numerous structural solutions (such as the discipline and stability rule in public finance regulations, salary limits in public entities, a ban on regulations that increased spending, and fiscal rules for local authorities) (Information 2014, p. 9). On 19 June 2015, the ECOFIN Council decided to lift the excessive deficit procedure from Poland, and at the end of 2015 the ratio of public finance to GDP settled at $-2.6 \%$.

Despite the steady real growth of GDP and the significant depreciation of the zloty after 2009, in the period under analysis Poland consistently recorded a current account deficit. This was mainly caused by deficits in trade and in the current account (the result of including people not resident in Poland), partially balanced by fund transfers from the EU (Sawicki 2014, p. 101; Kuziemska 2012, p. 210) (the current account deficit itself was

\footnotetext{
${ }^{2}$ Statement by S. Owsiak in a recording of a panel discussion entitled "The Desired Directions and Scenarios for Fixing Public Finance in Poland", published in Ekonomiczne i prawne uwarunkowania $i$ bariery redukcji deficytu i dtugu publicznego [Economic and legal conditions and barriers for the reduction of the deficit and public debt] (Szołno-Koguc \& Pomorska 2011, p. 27).
} 
financed from the surplus in the capital account). The reduction of the deficit which started in 2013 (in 2015 the current account deficit stood at $-0.6 \%$ of the GDP) was mainly associated with a positive trade balance caused by the economic recovery in Western Europe. According to the catching-up theory, a negative current account balance is typical for countries that are catching-up.

\section{Measures of Macroeconomic Stability - Poland against the Backdrop of EU Countries}

Based on the values of macroeconomic indicators (GDP, U, CPI, G, CA), partial measurements PSM1 and PSM2 as well as the synthetic measure PSM were established for the EU28 countries, Western Europe (the 10 "old" and most developed EU Member States), Central and Eastern Europe (countries that joined the EU in 2004, 2007 and 2013, except Cyprus and Malta), Southern Europe (PIIGS countries, Malta, and Cyprus), and Poland between 2006 and 2015. In the case of the aforementioned European regions, these were average values calculated using measurements obtained for individual countries. Figure 2 illustrates the changes to the total area of triangles a, b, c, d, e, which form the pentagon of economic stability for Poland and each region in the period under analysis (the lengths of the sides of the regional pentagons were the average length measured for individual Member States) with a CPI value limit of $-2.0 \%$, while Figure 3 illustrates the corresponding changes with a CPI value limit of $+1.0 \%$ (scale with regression). Comparisons of the values of the averaged indicators with the indicators gathered for Poland are illustrated in Figures $4 a-6 a$ and $4 b-6 b$, respectively.

Due to the low intensity of deflationary processes in Europe, the conclusions from an analysis based on the modified classic scale and the scale with regression are similar. Based on an analysis of Figures $4 \mathrm{a}$ and $4 \mathrm{~b}$, it can be established that in the years 2008-2009 (that is, during the last global financial crisis) the MSP indicator in all the examined EU regions decreased (in Poland and in the countries of Southern Europe the downward trend persisted in 2010), whereas the 2010-2011 period is basically the beginning of a rising trend which lasts until the end of the period under analysis (in Western Europe, this trend began in 2013), as well as an increase in the level of macroeconomic stability. In the 2014-2015 period, in all the regions apart from Western Europe, stability exceeded the levels observed before the crisis. West European countries were, however, 

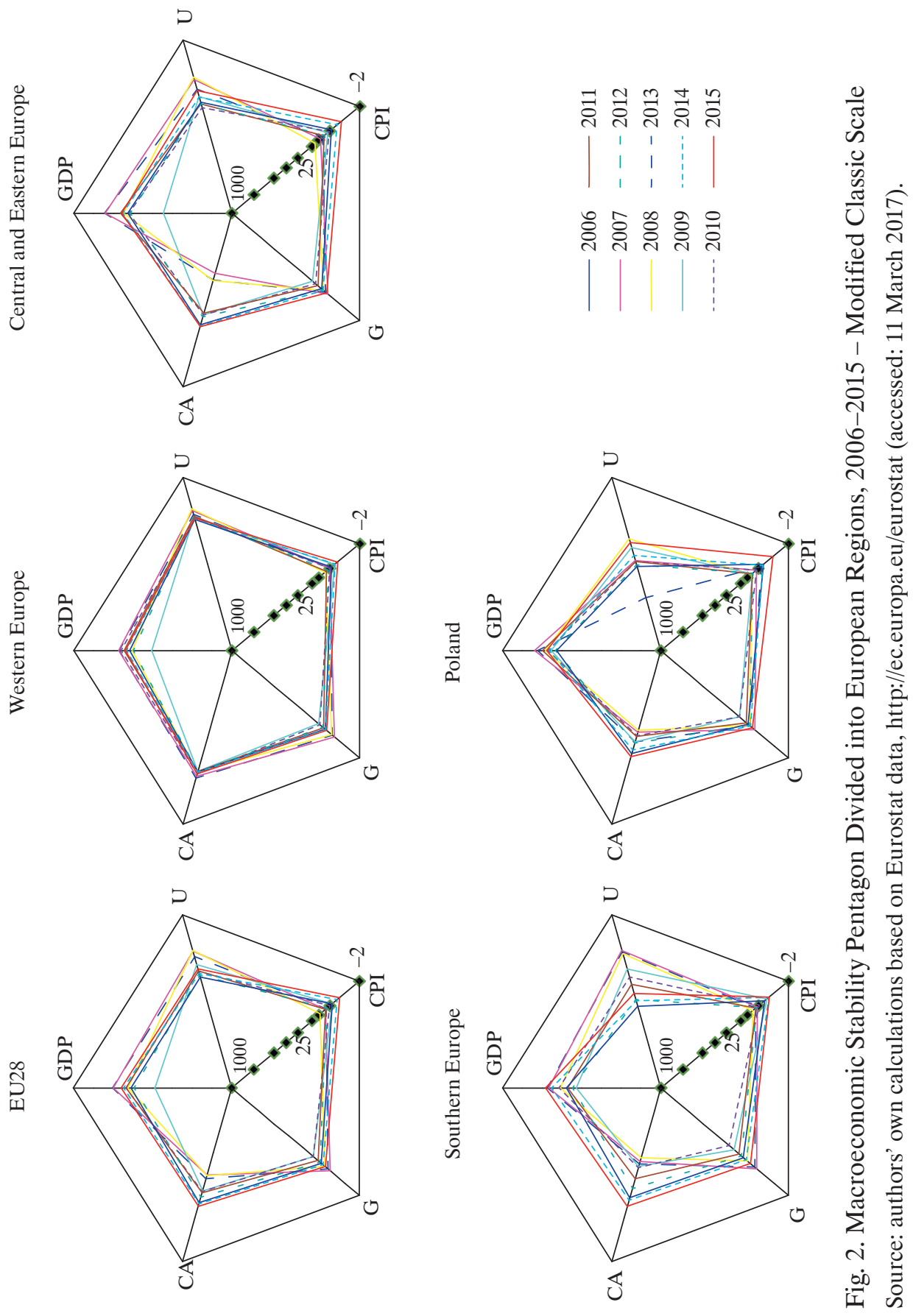
24 Aleksandra Jurkowska, Michał Boda

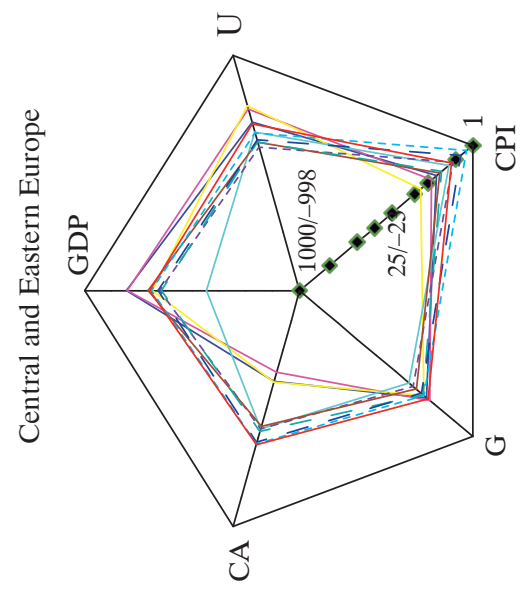

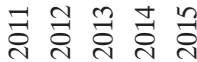
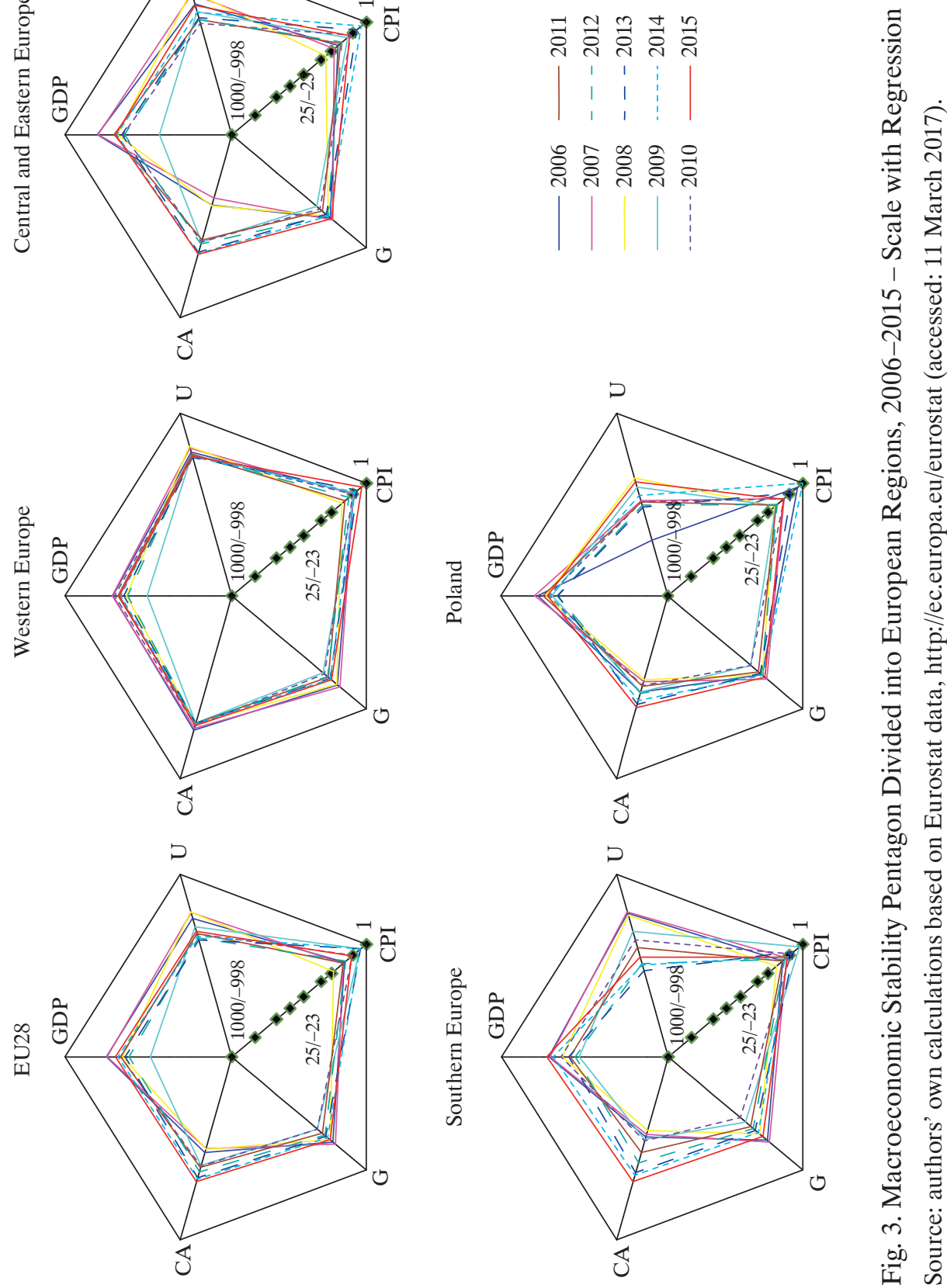

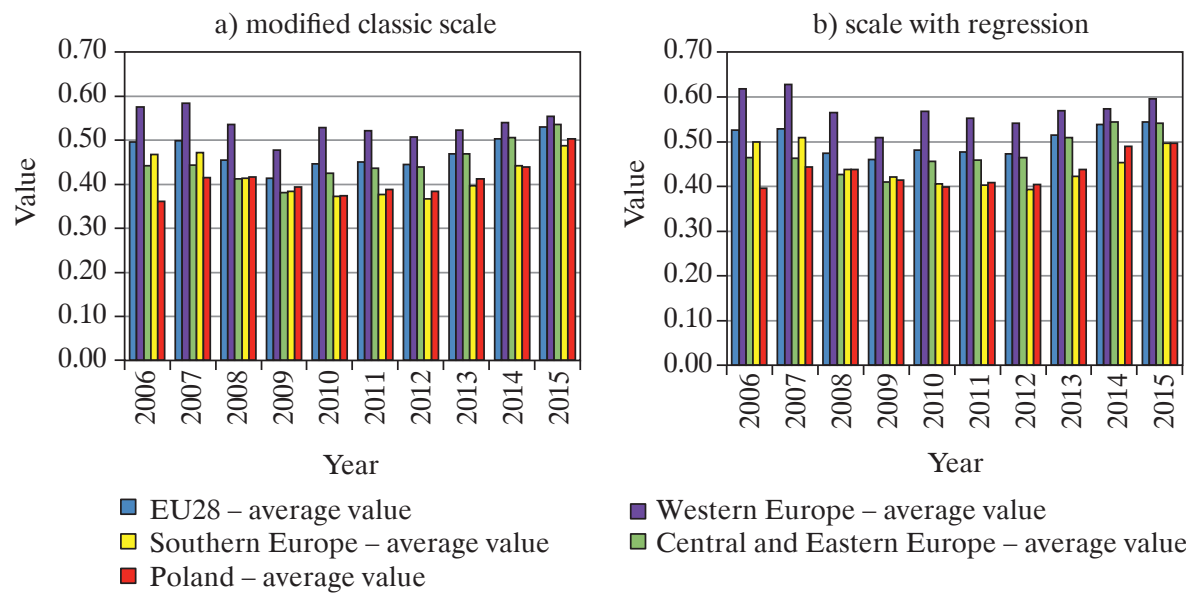

$\square$ Western Europe - average value

$\square$ Central and Eastern Europe - average value

Fig. 4. Synthetic MSP Indicators for Poland and Specified European Regions, 2006-2015

Source: authors' own calculations based on Eurostat data, http://ec.europa.eu/eurostat (accessed: 11 March 2017).

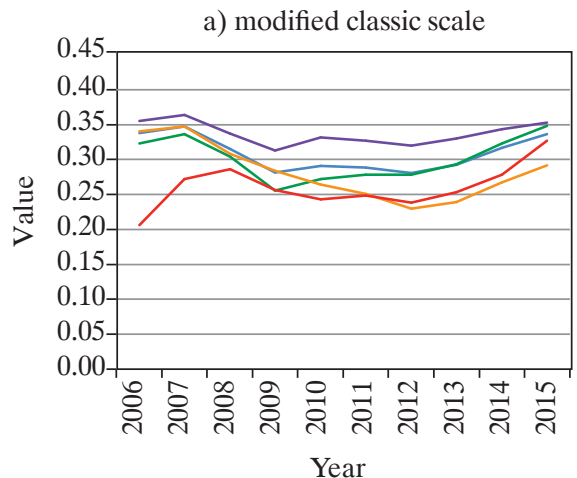

EU28 - average value

Southern Europe - average value

Poland - average value b) scale with regression

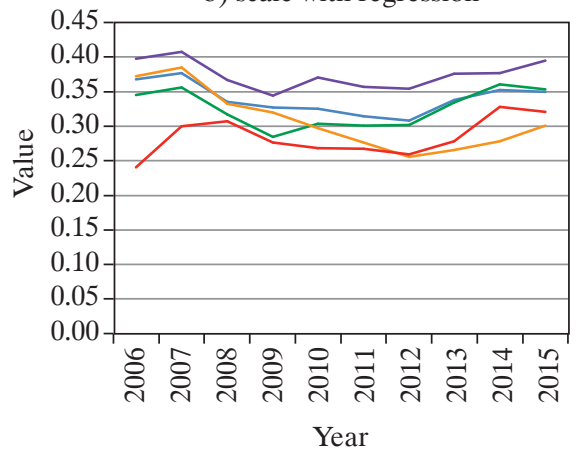

Western Europe - average value

Central and Eastern Europe - average value

Fig 5. MSP1 Indicator for Poland and Specified European Regions, 2006-2015

Source: authors' own calculations based on Eurostat data, http://ec.europa.eu/eurostat (accessed: 11 March 2017).

the most economically stable over the whole period under analysis (they had the highest values of PSM, PSM1, and PSM2 among all the reviewed groups; cf. Figures $5 \mathrm{a}$ and $5 \mathrm{~b}$ as well as $6 \mathrm{a}$ and $6 \mathrm{~b}$ ). After the crisis, Southern 
a) modified classic scale

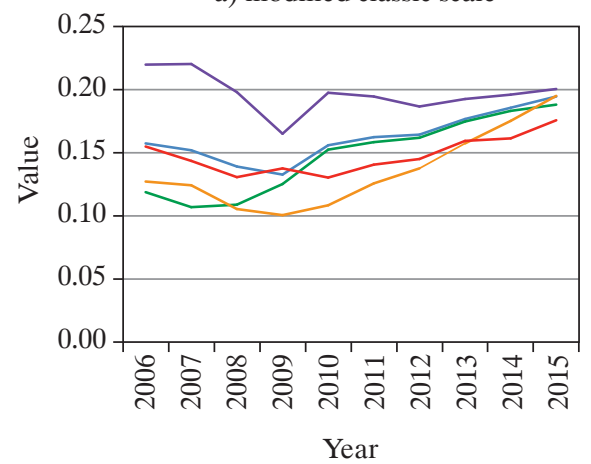

Year

EU28 - average value
Southern Europe - average value

_ Poland - average value

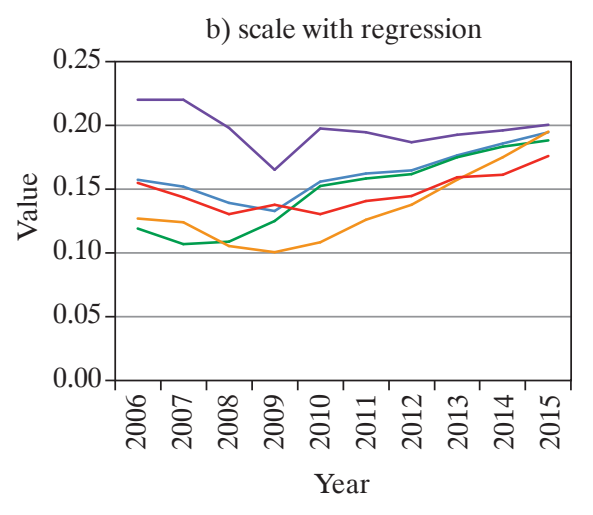

Western Europe - average value

Central and Eastern Europe - average value

Fig. 6. MSP2 Indicator for Poland and Specified European Regions, 2006-2015

Source: authors' own calculations based on Eurostat data, http://ec.europa.eu/eurostat (accessed: 11 March 2017).

European countries were left with the lowest levels of the MSP indicator. The average level of macroeconomic stability of the Central and East European countries was consistently close to the corresponding average for the EU28, and in the 2014-2015 period it exceeded it slightly. An analysis of Figure 2 and of the length of the sides of the pentagons drawn for the different groups of countries points to the conclusion that the main negative factors influencing the synthetic MSP measurement were:

- for West European countries - the drop in the rate of economic growth during the 2008-2009 period,

- for Central and East European countries - the drop in the rate of economic growth in 2009, the high unemployment rate in the 2010-2013 period, and the deficit in the current account in the 2006-2008 period,

- for Southern European countries - the slow rate of economic growth in the 2008-2012 period, the high unemployment rate in the 2009-2015 period, and the deficit in the current account in the 2006-2011 period.

The shape of the pentagon for the EU28 is a result of the aforementioned trends.

In the case of Poland, despite the clear increase in the MSP indicator during the 2013-2015 period, its value over the whole period was basically below the average values for the EU28, Western Europe, and Central and Eastern Europe (in the case of the latter, the crisis years of 2008-2009 
were an exception) and above the average recorded in Southern European countries (with the exception of the 2006-2008 and 2014 periods).

An analysis of the partial indicators MSP1 and MSP2 (Figures 5a and $5 \mathrm{~b}$ as well as $6 \mathrm{a}$ and $6 \mathrm{~b}$ ) allows for more detailed conclusions regarding the potential direction of macroeconomic policy changes in Poland. The MSP1 indicator for Poland over the whole period of analysis was lower than the average calculated for the countries of the EU28, Western Europe, and Central and Eastern Europe, and until and including 2011 - also lower than the average for the countries of Southern Europe. From 2012, the indicator in Poland exceeded the levels observed in Southern Europe. Additionally, using the scale with regression indicates that in the years 2014 and 2015, Poland experienced a noticeable increase and then a drop in the stability of the internal sphere (which is not reflected when using the modified classic scale). Until and including 2009, the MSP2 indicator in Poland was close to the average for the EU28 and higher than the average for Central and East European countries, and until and including 2013 - higher than the average for Southern Europe. In the 2014-2015 period, Poland had the lowest level of the MSP2 indicator among all the country groups under review. Based on the lengths of the sides of the pentagon drawn for Poland, it can be concluded that the factors which positively influenced the state of the internal sphere were the positive rate of economic growth and low inflation. A decidedly negative factor for the value of MSP1 was the high rate of unemployment, which over the entire period under analysis exceeded the EU28 average and partially nullified the positive effects of GDP and CPI. For Poland, the relatively low MSP2 values were due to the strongly negative (until 2012) ratio of the current account balance to GDP, which in the 2009-2011 period coincided with a high ratio of budget deficit to GDP.

\section{Conclusions}

The analysis presented here allows for the conclusion that in recent years the EU28 countries have returned to the level of macroeconomic equilibrium from before the crisis of 2008-2009. In the majority of the countries, including Poland, this level was even exceeded in the 2014-2015 period. The exception was the West European countries, although this group had the highest MSP values over the whole period under analysis. Although the MSP indicator rose in Poland from 2013 and was higher than the levels observed in Southern European countries, until 2015 it was still lower than the level for the EU28 and also the average levels set for the Central 
and East European countries. This state of affairs was mainly caused by the high level of unemployment, which despite a downward trend was consistently above the EU average. Until 2012, the level of macroeconomic stability in Poland was negatively influenced by a relatively high current account deficit, and in the 2009-2011 period - by a high budget deficit (with the consequence that Poland was placed under the excessive deficit procedure). As much as a negative current account balance is characteristic of "catching-up countries" and has recently been significantly reduced, the level of unemployment in Poland is mainly shaped by demand. It is therefore expected that this problem will continue to present a challenge for future economic policy goals.

\section{Bibliography}

Albiński, P. (2014) "Kryzysy i polityka stabilizacyjna w Unii Europejskiej” [Crises and stabilisation policy in the European Union] in P. Albiński (ed.) Kryzys a polityka stabilizacyjna w Unii Europejskiej [The crisis versus stabilisation policy in the European Union]. Warsaw: Oficyna Wydawnicza Szkoła Główna Handlowa w Warszawie.

AMECO (2016) "Forecast for 2013 from the European Commission Spring Forecast" cited in L. Balcerowicz, A. Rzońca, L. Kalina and A. Laszek Economic Growth in the European Union. Lisbon Council E-book. Brussels: Lisbon Council asbl.

Balcerowicz, L., Rzońca, A., Kalina, L. and Łaszek, A. (2013) Economic Growth in the European Union. Lisbon Council E-book. Brussels: Lisbon Council asbl.

Baldini, I. and Manasse, P. (2013) "What's Wrong with Europe", http://voxeu.org/article/ what-s-wrong-europe (accessed: 5 August 2016).

Baranowski, P. (2008) Problem optymalnej stopy inflacji $w$ modelowaniu wzrostu gospodarczego [The optimal inflation rate problem in economic growth modelling]. Łódź: Wydawnictwo Biblioteka.

Bartosik, K. (2012) "Popytowe i podażowe uwarunkowania polskiego bezrobocia" [The influence of supply and demand on Polish unemployment]. Gospodarka Narodowa 11-12: 255-256, LXXX/XXI, November-December.

Bednarczyk, J. L. (2015) "Polityka pieniężna Europejskiego Banku Centralnego a zagrożenie deflacją w Unii Europejskiej" [Monetary policy of the European Central Bank and the threat of inflation in the European Union]. Kwartalnik Kolegium Ekonomiczno-Spotecznego Studia i Prace 1 (3): Bankowość. Sieć bezpieczeństwa i otoczenie jego banków [Banking: A safety net around the banks], SGH.

Belke, A. and Dreger, C. (2011) "Current Account Imbalances in the Euro Area: Catching Up or Competitiveness?". DIW Discussion Paper 1106. Berlin, February.

Bogdan, W., Boniecki, D., Labaye, E., Marciniak, T. and Nowacki, M. (2015) "Poland 2025: Europe's New Growth Engine". McKinsey\&Company, http://mckinsey.pl/ wp-content/uploads/2015/10/Poland-2025_full_report.pdf (accessed: 11 March 2017). 
Budgetary (2016) "Budżetowa strefa zagrożenia. Ranking państw UE z najwyższym i najniższym deficytem do 2017 roku" [Budgetary danger zone. Ranking of EU countries with the highest and lowest deficit until 2017]. Forsal.pl, 24 March.

Ducrozet, F., Kukla, B. and Lacan, A. (2011) "Are EBC Rate Hikes Going to Finish Off the Periphery?". Consensus Economics 5 (3). Warsaw: Ministry of Finance.

EC (2015) "Commission Staff Working Document. Country Report Poland 2015 $\{$ COM(2015) 85 final $\} "$. Brussels: European Commission, SWD(2015) 40 final.

EC (2014) "European Economic Forecast. Winter 2014". European Economy 02. European Commission Directorate-General for Economic and Financial Affairs.

EC (2016) "Spring 2016 European Semester Package: Commission Issues Country-specific Recommendations". European Commission press release, Brussels, 18 May.

European Parliament (2015) "Understanding Deflation. Falling Prices and Their Impact on the Economy". European Parliament briefing, June.

Giżyński, J. (2012) "Konsolidacja fiskalna w krajach Unii Gospodarczej i Walutowej w warunkach kryzysu zadłużenia" [Fiscal consolidation under debt crisis conditions in the Economic and Monetary Union countries]. Zarzadzanie i Finanse 10 (4) (1).

Głąbicka, K. (2001) Wybrane elementy rynku pracy [Selected elements of the labour market]. Warsaw: Wydawnictwo Wyższej Szkoły Pedagogicznej TWP.

Hajder, K. (2013) "Bezrobocie w Unii Europejskiej w świetle kryzysu gospodarczego lat 2008-2013" [Unemployment in the European Union in the light of the economic crisis of 2008-2013]. Rocznik Integracji Europejskiej 7, https://doi.org/10.14746/rie.2015.9.28.

Information (2014) "Informacja o działaniach podjętych przez Polskę w celu realizacji rekomendacji Rady w ramach procedury nadmiernego deficytu" [Information about the actions taken by Poland in the implementation of Council recommendations regarding the excessive deficit procedure]. Warsaw, April, http://www.mf.gov.pl/ documents/764034/1002171/EDP+raport+2014.04.pdf (accessed: 11 March 2017).

Kołodko, G. (1993) Kwadratura pięciokata. Od załamania gospodarczego do trwatego wzrostu [The squareness of a pentagon. From economic downturn to steady growth]. Warsaw: Poltext.

Kostanciak, W. (2011) "Przemiany deficytu budżetowego w Polsce w latach 1992-2009" [Budget deficit changes in Poland between 1992-2009]. Studia i Prace Wydziatu Nauk Ekonomicznych i Zarządzania 22. Szczecin: Wydawnictwo Naukowe Uniwersytetu Szczecińskiego.

Kuziemska, K. (2012) "Determinanty salda rachunku obrotów bieżących Polski w latach 2000-2011" [Polish current account balance determinants in the years 2000-2011]. Acta Universitatis Lodziensis. Folia Oeconomica 273.

Kuziemska, K. (2010) "Problem nierównowag na rachunkach obrotów bieżących w strefie euro" [The problem of imbalance in the current accounts of the Eurozone]. Acta Universitatis Lodziensis. Folia Oeconomica 238.

Lubieniecka, M. (2013) "Budżet państwa w obliczu wahań koniunktury gospodarczej na przykładzie gospodarki polskiej" [National budget in the face of economic fluctuations on the example of the Polish economy]. Nierówności spoteczne a wzrost gospodarczy 30. Rzeszów: Wydawnictwo Uniwersytetu Rzeszowskiego.

Malinowski, D. (2012) "Determinanty zmian deficytu budżetu państwa i długu publicznego w państwach Unii Europejskiej w 2010 roku" [Determinants of change in the budget deficit and public debt in European Union countries in 2010]. Kwartalnik Kolegium Ekonomiczno-Społecznego Studia i Prace 2, SGH. 
Mastromatteo, G. and Rossi, S. (2015) "The Economics of Deflation in the Euro Area: a Critique of Fiscal Austerity". Review of Keynesian Economics 3 (3), Autumn, https:// doi.org/10.4337/roke.2015.03.04.

Ministry of Finance (2012) "Finanse publiczne w Polsce w okresie kryzysu" [Public finance in Poland during the crisis].

MPC (2015) "Raport o inflacji” [Inflation report]. Monetary Policy Council. Warsaw: National Bank of Poland, November.

Polakowski, M. and Szelewa, D. (2013) Bezrobocie w Polsce: polityka państwa a indywidualne strategie [Unemployment in Poland: national policy versus individual strategies]. Warszawskie debaty o polityce społecznej, ICRA. Warsaw: Friedrich Ebert Stiftung.

Raczkowski, R. (2016) "Makroekonomiczne stabilizatory procesu zarządzania publicznego w państwach Unii Europejskiej" [Macroeconomic stabilisers of the public management process in European Union countries]. Przeglad Organizacji 9.

Sawicki, J. (2014) "Dynamika zmian w bilansie płatniczym krajów Unii Gospodarczej i Walutowej - wnioski dla Polski" [The dynamics of change in the balance of payments of the Economic and Monetary Union countries - suggestions for Poland]. Gospodarka Narodowa 1 (269), LXXXIV/XXV, January-February.

Siek E. (2015) "Pięciokąt stabilizacji makroekonomicznej. Materiały dydaktyczne" [Macroeconomic Stability Pentagon. Educational materials]. Katedra Biznesu i Finansów Międzynarodowych. Uniwersytet Technologiczno-Humanistyczny im. K. Pułaskiego w Radomiu, uniwersytetradom.pl/files/get_userfile.php?id=7889. 2015.03.04 (accessed: 11 March 2017).

Szołno-Koguc, J. and Pomorska, A. (eds) (2011) Ekonomiczne i prawne uwarunkowania $i$ bariery redukcji deficytu $i$ dtugu publicznego [Economic and legal considerations and barriers in reducing public debt and deficit]. Warsaw: Lex a Wolters Kluwer business.

Walawski, M. (2015) "Stabilizacja makroekonomiczna gospodarki rosyjskiej w latach 1997-2012" [Macroeconomic stabilisation of the Russian economy in the period 1997-2012]. Studia Oeconomica Posnaniensia 3 (4).

World Bank (2015) "EU Regular Economic Report. Modest Recovery, Global Risks". World Bank Group, Final Report.

\section{Abstract}

\section{Stabilność makroekonomiczna w Polsce na tle tendencji unijnych w świetle koncepcji PSM}

Celem artykułu jest analiza tendencji w zakresie kształtowania się czynników determinujących poziom stabilizacji makroekonomicznej oraz ocena tego poziomu w Polsce na tle różnych grup krajów Unii Europejskiej (kraje UE28, Europy Zachodniej, Europy Środkowo-Wschodniej oraz Europy Południowej) w latach 2006-2015 z wykorzystaniem metody pięciokąta stabilizacji makroekonomicznej (PSM). Przedmiotem analizy w prezentowanej metodzie są tempo wzrostu gospodarczego (GDP), stopa bezrobocia (U), stopa inflacji (CPI), saldo finansów publicznych $(\mathrm{G})$ oraz saldo bieżących obrotów z zagranicą (CA), których wartości stanowią wierzchołki pięciokąta wyskalowanego w ten sposób, że im bardziej pożądane są wartości wskaźników, tym obrazu- 
jące je punkty znajdują się dalej od środka układu. W artykule zaproponowano wyznaczenie łącznego pola PSM na podstawie zmodyfikowanej skali klasycznej oraz skali z regresem (podejścia odpowiednio nieuwzględniające oraz uwzględniające negatywne oddziaływanie zjawisk deflacyjnych na ogólny poziom stabilizacji makroekonomicznej). Przeprowadzone analizy pozwalają sformułować wniosek, że w ostatnich latach kraje EU28 powróciły do poziomu równowagi makroekonomicznej sprzed kryzysu w latach 2008-2009. W Polsce wskaźnik PSM wzrastał od 2013 r. i zasadniczo przekraczał poziomy obserwowane w odniesieniu do krajów Europy Południowej, jednak do $2015 \mathrm{r}$. jego poziom był wciąż niższy od średniej dla UE28 oraz od średniej wyznaczonej dla krajów Europy Środkowo-Wschodniej. Na taki stan rzeczy wpływała głównie wysoka stopa bezrobocia, która pomimo tendencji spadkowej wciąż utrzymywała się powyżej przeciętnej unijnej.

Słowa kluczowe: polityka gospodarcza, wskaźniki makroekonomiczne, stabilizacja makroekonomiczna, pięciokąt stabilizacji makroekonomicznej (PSM), wskaźnik PSM. 